\title{
HUBUNGAN MEKANISME CORPORATE GOVERNANCE DAN KINERJA KEUANGAN BANK PEMBIAYAAN RAKYAT SYARIAH
}

\author{
Eriza Mayang Kusuma \\ Fakultas Ekonomi dan Bisnis, Universitas Kristen Satya Wacana \\ Supatmi \\ Fakultas Ekonomi dan Bisnis, Universitas Kristen Satya Wacana \\ patmie@staff.uksw.edu
}

\begin{abstract}
This study aims to find the empirical evidence about the correlation of corporate governance with the financial performance of Islamic rural bank (Bank Pembiayaan Rakyat Syariah/BPRS). The samples are 97 Islamic rural banks in Indonesia, which published financial statements during 2011-2012. The corporate governance mechanism is measured by independent board, board of directors, managerial and institutional ownership. Financial performance is measured by financial ratios, i.e. NPF, CAR, FDR, ROA and ROE. The hypotheses are tested using Chi square test. This study showed that the board of director was positively related to the ability to cope with the level of non performing loans (NPF), both managerial and institutional ownership was positively related to the return on assets and equity (ROA and ROE).
\end{abstract}

Keywords: corporate governance mechanism, financial performance, Islamic rural bank

\section{PENDAHULUAN}

Penerapan prinsip-prinsip good corporate governance (GCG) merupakan suatu hal penting yang harus dilakukan bagi sebuah organisasi, termasuk bagi lembaga keuangan seperti perbankan syariah. Hal tersebut dipertegas dalam Peraturan Bank Indonesia (PBI) Nomor 8/4/PBI/2006 tanggal 30 Januari 2006 tentang pelaksanaan good corporate governance bagi bank umum. Aturan tersebut kembali disempurnakan melalui PBI Nomor 8/14/PBI/2006 tanggal 5 Oktober 2006, dan kemudian disempurnakan lagi dengan PBI Nomor 11/33/PBI/2009 tanggal 7 Desember 2009 dan Surat Edaran Bank Indonesia (BI) Nomor 12/13/DPbs tanggal 30 April 2010 tentang pelaksanaan good corporate governance bagi bank umum syariah dan unit usaha syariah.

Pelaksanaan tata kelola tidak lepas dari organ-organ yang ada dalam perusahaan, yang juga merupakan bagian dari mekanisme tata kelola. Menurut 
Syakhroza (2002), mekanisme corporate governance dapat diartikan sebagai suatu aturan main, prosedur dan hubungan yang jelas antara pihak yang mengambil keputusan dengan pihak yang akan melakukan pengawasan terhadap keputusan tersebut. Secara umum mekanisme corporate governance (CG) yang dapat berjalan baik akan terefleksi dalam kinerja perusahaan yang baik pula.

Berbagai penelitian yang menghubungkan kinerja keuangan perbankan dengan mekanisme corporate governance menemukan hasil penelitian yang bervariasi. Penelitian Rusmaryati (2012) membuktikan mekanisme corporate governance (diukur dari ukuran dewan komisaris, ukuran dewan direksi dan auditor eksternal) berpengaruh terhadap CAEL yaitu capital, assets, earnings dan liquidity di perbankan konvensional yang terdaftar di Bursa Efek Indonesia tahun 2009-2011. Sedangkan keberadaan pemegang saham pengendali, proporsi dewan komisaris independen dan komite audit menunjukkan pengaruh negatif terhadap kinerja keuangan perbankan. Andriyan dan Supatmi (2010) membuktikan mekanisme CGI secara simultan berpengaruh terhadap rasio non performing loan (NPL), kewajiban penyediaan modal minimum (KPMM), dan return on assets (ROA) di bank perkreditan rakyat (BPR) swasta yang beroperasi di Jawa Tengah. Secara parsial, kepemilikan manajerial dan proporsi outside directors menunjukkan pengaruh negatif terhadap rasio NPL dan ROA, sedangkan jumlah board of directors (BOD) berpengaruh negatif terhadap rasio loan to deposit ratio (LDR).

BPR konvensional dan BPR syariah (selanjutnya disingkat BPRS) memiliki perbedaan utama dalam hal pengelolaannya, dimana pengelolaan BPRS harus berdasarkan prinsip syariah dengan sistem bagi hasil yang sifatnya berfluktuasi tergantung pada pendapatan yang diperoleh BPRS dan nisbah yang disepakati. Sedangkan BPR konvensional yang menggunakan sistem bunga pasti akan memampukan bank untuk mengatur strategi dan kebijakan yang jelas agar bunga pinjaman dapat menutup bunga simpanan. Dari sisi manajemen, BPRS memiliki dewan pengawas yang disebut Dewan Pengawas Syariah (DPS). DPS yang terdapat dalam struktur kepemimpinan BPRS memiliki fungsi yang sama dengan auditor internal, yakni melakukan pengawasan secara periodik pada lembaga keuangan syariah yang berada di bawah pengawasannya. Adanya DPS dalam struktur kepemimpinan BPRS diharapkan akan lebih memperkuat pengawasan di BPRS.

Berdasarkan hal tersebut, penelitian ini bertujuan untuk menemukan bukti empiris mengenai hubungan mekanisme corporate governance terhadap kinerja keuangan BPRS di Indonesia. Mekanisme corporate governance akan dilihat dari aspek dewan direksi, dewan komisaris independen, kepemilikan manajerial dan kepemilikan institusional. Sedangkan kinerja keuangan BPRS akan diukur dari return on assets (ROA), kewajiban penyediaan modal minimum (KPMM), financing to deposit ratio (FDR), rasio non performing financing (NPF) dan return on equity (ROE). Hasil dari penelitian ini diharapkan dapat memberi manfaat bagi BPRS sebagai masukan perumusan strategi untuk meningkatkan kinerja keuangan BPRS 
dengan menyadari peran penerapan mekanisme corporate governance dalam aktivitas pengelolaan perusahaan.

\section{TELAAH PUSTAKA}

\section{Bank Pembiayaan Rakyat Syariah (BPRS)}

Bank Pembiayaan Rakyat Syariah (BPRS) merupakan Bank Perkreditan Rakyat (BPR) yang melakukan kegiatan usaha berdasarkan prinsip syariah, yang selanjutnya diatur menurut Surat Keputusan Direktur Bank Indonesia No. 32/36/KEP/DIR/1999 tanggal 12 Mei 1999 tentang bank perkreditan rakyat berdasarkan prinsip syariah. Secara teknis BPRS bisa diartikan sebagai lembaga keuangan sebagaimana BPR konvensional, yang operasinya menggunakan prinsipprinsip syariah terutama bagi hasil. Sebagai lembaga keuangan syariah, pada dasarnya BPRS dapat memberikan jasa-jasa keuangan yang serupa dengan bankbank umum syariah. Namun demikian, sesuai UU Perbankan No. 10 tahun 1998, BPRS hanya dapat melaksanakan usaha-usaha berikut ini: (1) menghimpun dana dari masyarakat dalam bentuk simpanan berupa deposito berjangka, tabungan dan atau bentuk lainnya yang dipersamakan dengan itu; (2) memberikan kredit; (3) menyediakan pembiayaan dan penempatan dana berdasarkan prinsip syariah sesuai dengan ketentuan yang ditetapkan oleh Bank Indonesia dan (4) menempatkan dananya dalam bentuk Sertifikat Bank Indonesia, deposito berjangka, sertifikat deposito dan atau tabungan pada bank lain. Pembatasan usaha BPRS secara lebih tegas dijelaskan dalam pasal 27 SK Direktur BI No. 32/36/KEP/DIR/1999.

Penilaian kinerja keuangan BPRS dapat dilakukan dengan menganalisis laporan keuangan yang diterbitkan diantaranya dengan menggunakan rasio yaitu $N P F$, KPMM, FDR, ROA dan ROE berikut ini.

1. $\quad$ Non performing financing (NPF)

Rasio NPF merupakan rasio yang menunjukkan kemampuan bank dalam mengatasi pembiayaaan bermasalah (kredit macet) atas total pembiayaan pada bank tersebut. Menurut Surat Edaran BI Nomor 9/29 DPbS tentang Sistem Penilaian Kesehatan BPRS, kinerja NPF diklasifikasikan sangat tinggi (baik) apabila kurang dari 7 persen.

2. Kewajiban penyediaan modal minimum (KPMM)

KPMM adalah rasio yang memperlihatkan seberapa besar jumlah seluruh aktiva bank yang mengandung risiko (kredit, penyertaan, surat berharga, tagihan pada bank lain) yang ikut dibiayai dari modal sendiri di samping memperoleh danadana dari sumber-sumber diluar bank. Menurut Surat Edaran BI Nomor 9/29 DPbS tentang Sistem Penilaian Kesehatan BPRS, kinerja KPMM diklasifikasikan sangat kuat apabila lebih dari 11 persen. 
3. Financing to deposit ratio (FDR)

FDR adalah rasio yang menyatakan seberapa jauh kemampuan bank dalam membayar kembali penarikan dana yang dilakukan nasabah dengan mengandalkan kredit yang diberikan sebagai sumber likuiditasnya. Menurut Surat Edaran BI Nomor 9/29 DPbS tentang Sistem Penilaian Kesehatan BPRS, kinerja FDR diklasifikasikan sangat tinggi apabila lebih dari 93 persen.

4. Return on asset (ROA)

Rasio ini digunakan untuk mengukur kemampuan manajemen bank dalam memperoleh keuntungan atau laba secara keseluruhan. Menurut Surat Edaran BI Nomor 9/29 DPbS tentang Sistem Penilaian Kesehatan BPRS, kinerja ROA diklasifikasikan sangat tinggi apabila lebih dari 1,45 persen.

5. Return on equity (ROE)

$R O E$ merupakan rasio atau nisbah profitabilitas yang mengukur tingkat kemampuan modal dalam menghasilkan laba bersih. Menurut Surat Edaran BI Nomor 9/29 DPbS tentang Sistem Penilaian Kesehatan BPRS, kinerja ROE diklasifikasikan sangat tinggi apabila lebih dari 23 persen.

\section{Mekanisme Corporate Governance}

Menurut Daniri (2005) mekanisme corporate governance adalah suatu pola hubungan, sistem dan proses yang digunakan oleh organ perusahaan (direksi, dewan komisaris, RUPS) guna memberikan nilai tambah kepada pemegang saham secara berkesinambungan dalam jangka panjang dengan tetap memperhatikan kepentingan stakeholders lainnya, berlandaskan peraturan dan perundangan serta norma yang berlaku. Banhart dan Rosenstein (1998) dalam Purwaningtyas (2011) menyatakan bahwa mekanisme corporate governance dibagi menjadi dua kelompok. Pertama, berupa internal mechanisms (mekanisme internal) seperti komposisi dewan direksi atau komisaris, kepemilikan manajerial dan kompensasi eksekutif. Kedua, external mechanisms (mekanisme eksternal) seperti pengendalian oleh pasar dan level of debt financing. Babic (2001) dalam Nuryaman (2009) menyatakan bahwa mekanisme corporate governance dapat berupa mekanisme internal, yaitu struktur kepemilikan yang salah satu aspeknya adalah konsentrasi kepemilikan saham, struktur dewan komisaris yang salah satu aspeknya adalah komposisi dewan komisaris dan mekanisme eksternal yaitu pengendalian oleh pasar, kepemilikan institusional serta audit oleh auditor eksternal. Mekanisme corporate governance dalam penelitian ini diproksikan oleh tiga aspek mekanisme internal, yaitu dewan komisaris independen, dewan direksi dan kepemilikan manajerial serta satu mekansime eksternal yaitu kepemilikan institusional.

\section{Hubungan Dewan Komisaris Independen dengan Kinerja Keuangan BPRS}

Komisaris independen adalah anggota dewan komisaris yang tidak memiliki hubungan keuangan, kepengurusan, kepemilikan saham dan/atau hubungan keluarga dengan anggota dewan komisaris lainnya, direksi dan/atau pemegang saham 
pengendali atau hubungan dengan perseroan, yang dapat memengaruhi kemampuannya untuk bertindak independen. Proporsi dewan komisaris independen diukur dengan menggunakan indikator persentase anggota dewan komisaris yang berasal dari luar perusahaan, dari seluruh ukuran anggota dewan komisaris independen. Surat Keputusan Direksi Bursa Efek Jakarta no. Kep-399/BEJ/07-2001 butir $\mathrm{C}$ yang menyatakan bahwa jumlah komisaris independen yang harus terdapat dalam perusahaan sekurang-kurangnya 30 persen dari seluruh anggota dewan. Menurut Wardhani (2006) dalam Noorizkie (2013), peran dewan komisaris dalam suatu perusahaan lebih ditekankan pada fungsi monitoring dari implementasi kebijakan direksi. Peran komisaris ini diharapkan akan meminimalkan permasalahan keagenan yang timbul antara dewan direksi dengan pemegang saham. Sehingga apabila semakin banyak komisaris independen, maka pengawasan akan semakin ketat sehingga agency problem semakin kecil.

Berbagai penelitian menunjukkan hasil bahwa dewan komisaris independen berhubungan positif dengan kinerja keuangan perusahaan. Semakin tinggi persentase dewan komisaris independen dalam BPRS, maka diharapkan laporan keuangan BPRS dapat disusun secara independen pula karena dewan pengawas yang ada di BPRS tersebut tidak memiliki kepentingan pribadi. Semakin banyak jumlah dewan komisaris yang independen, maka semakin terlepas pula penyusunan laporan keuangan dari unsur kepentingan pribadi sehingga laporan keuangan dapat disusun sedemikian rupa dan mewakili kenyataan yang sesungguhnya terjadi. Hasil penelitian Dhanis (2012), Diandono (2012) dan Widiawati (2011) membuktikan bahwa terdapat pengaruh positif antara proporsi dewan komisaris independen terhadap kinerja perusahaan. Berdasarkan uraian di atas maka dapat diambil hipotesis sebagai berikut.

H1: Terdapat hubungan positif antara dewan komisaris independen dengan kinerja keuangan BPRS.

\section{Hubungan Dewan Direksi dengan Kinerja Keuangan BPRS}

Undang-undang Nomor 40 Tahun 2007 tentang perseroan terbatas menyatakan bahwa dewan direksi adalah organ perseroan yang berwenang dan bertanggung jawab penuh atas pengurusan perseroan untuk kepentingan perseroan, sesuai dengan maksud dan tujuan perseroan serta mewakili perseroan, baik di dalam maupun di luar pengadilan sesuai dengan ketentuan anggaran dasar. Komite Nasional Kebijakan Governance (KNKG) 2006 menyatakan bahwa direksi sebagai organ perusahaan bertugas dan bertanggung jawab secara kolegial dalam mengelola perusahaan. Ukuran dewan direksi adalah jumlah dewan direksi dalam suatu perusahaan. Menurut Peraturan BI Nomor 11/23/PBI/2009 tentang Bank Pembiayaan Rakyat Syariah, jumlah anggota dewan direksi dalam suatu perusahaan paling sedikit dua orang. 
Menurut Andriyan dan Supatmi (2010) jika peran dan fungsi board of directors $(B O D)$ dalam BPR dijalankan dengan baik, maka diduga pihak manajemen akan lebih berhati-hati dalam pelaksanaan kegiatan operasional BPR, karena jumlah $B O D$ dinilai berkaitan dengan kuat lemahnya pengawasan terhadap manajemen BPR. Hal ini dapat mengurangi potensi kerugian akibat resiko operasional BPR sehingga dapat memengaruhi kinerja BPR dari waktu ke waktu. Semakin banyak dewan direksi dalam perusahaan akan memberikan suatu bentuk pengawasan terhadap kinerja perusahaan yang semakin baik. Dengan kinerja perusahaan yang baik dan terkontrol, maka akan menghasilkan profitabilitas yang baik.

Pearce dan Zahra (1992) dalam Widyati (2013) menyatakan bahwa peningkatan ukuran dewan direksi akan memberikan manfaat bagi perusahaan karena terciptanya network dengan pihak luar perusahaan dan menjamin ketersediaan sumber daya. Pernyataan ini didukung oleh hasil penelitian Hutapea (2013) serta Rusmaryati (2012) yang menyatakan bahwa ukuran dewan direksi berpengaruh positif terhadap kinerja keuangan perusahaan. Berdasarkan uraian di atas maka dapat diambil hipotesis sebagai berikut.

H2: Terdapat hubungan positif antara dewan direksi dengan kinerja keuangan BPRS.

\section{Hubungan Kepemilikan Manajerial dengan Kinerja Keuangan BPRS}

Boediono (2005) dalam Wahyuni dan Nuryaman (2010) mendefinisikan kepemilikan manajerial sebagai jumlah kepemilikan saham oleh pihak manajemen dari seluruh modal perusahaan yang dikelola. Semakin besar proporsi kepemilikan manajemen dalam suatu perusahaan, maka manajemen akan berupaya lebih giat dalam memenuhi kepentingan pemegang saham yang juga adalah dirinya sendiri. Menurut Andriyan dan Supatmi (2010) semakin tinggi kepemilikan manajerial, manajemen BPR akan memperoleh keuntungan bila perusahaan memperoleh laba. Maka dapat diduga bahwa manajemen BPR akan mempunyai dorongan untuk meningkatkan kinerjanya dengan berupaya untuk mengelola kredit yang disalurkan secara lebih hati-hati.

Semakin besar proporsi kepemilikan manajemen pada perusahaan, maka manajemen cenderung berusaha lebih giat untuk kepentingan pemegang saham yang tidak lain adalah dirinya sendiri. Dengan kepemilikan manajerial yang tinggi, manajer mempunyai hak suara yang tinggi sehingga manajer mempunyai posisi yang kuat untuk mengendalikan perusahaan, hal ini dapat menimbulkan masalah pertahanan, dalam artian adanya kesulitan bagi para pemegang saham eksternal untuk mengendalikan tindakan manajer.

Ardianingsih dan Ardiyani (2012) membuktikan bahwa kepemilikan manajerial berpengaruh negatif terhadap kinerja perusahaan. Melinda dan Sutejo (2008) membuktikan bahwa pengaruh antara kepemilikan manajerial dan kinerja 
keuangan perusahaan adalah positif dan tidak signifikan. Berdasarkan uraian di atas maka dapat diambil hipotesis sebagai berikut.

H3: Terdapat hubungan positif antara kepemilikan manajerial dengan kinerja keuangan BPRS.

\section{Hubungan Kepemilikan Institusional dengan Kinerja Keuangan BPRS}

Beiner et al. (2003) dalam Rahmayanti (2012) menyatakan kepemilikan institusional adalah jumlah persentase hak suara yang dimiliki oleh institusi. Persentase saham institusi ini diperoleh dari penjumlahan atas persentase saham perusahaan yang dimiliki oleh perusahaan lain baik yang berada di dalam maupun di luar negeri serta saham pemerintah dalam maupun luar negeri. Arifani (2012) menyatakan bahwa adanya kepemilikan institusional dianggap sebagai kontroler bagi perusahaan untuk menciptakan kinerja yang baik dan semakin meningkat. Pernyataan ini didukung dengan hasil penelitian dari Sekaredi (2011) dan Widyati (2013) yang membuktikan bahwa kepemilikan institusional berpengaruh positif terhadap kinerja keuangan perusahaan.

Tingkat kepemilikan institusional yang tinggi akan menimbulkan usaha pengawasan yang lebih besar oleh institusi pemegang saham, sehingga diharapkan dapat mengurangi tingkat penyelewengan-penyelewengan yang dilakukan oleh manajemen. Penyelewengan ini dikhawatirkan akan menurunkan nilai perusahaan. Semakin besar kepemilikan institusi keuangan maka akan semakin besar kekuatan suara dan dorongan dari institusi keuangan tersebut untuk mengawasi manajemen dan akibatnya akan memberikan dorongan yang lebih besar untuk mengoptimalkan nilai perusahaan, sehingga kinerja perusahaan akan meningkat. Berdasarkan uraian di atas maka dapat diambil hipotesis sebagai berikut.

H4: Terdapat hubungan positif antara kepemilikan institusional dengan kinerja keuangan BPRS.

\section{METODA PENELITIAN}

Populasi dalam penelitian ini adalah seluruh BPRS di Indonesia yang beroperasi selama tahun 2011-2012 yaitu sejumlah 160 BPRS. Teknik pengambilan sampel yang digunakan dalam penelitian ini purposive sampling, dengan kriteria BPRS yang terdaftar di BI, laporan keuangannya dipublikasikan di website resmi BI serta tersedia data-data yang dibutuhkan dalam penelitian. BPRS yang tidak mempublikasikan laporan keuangan tahun 2011 dan atau 2012 adalah 63 BPRS, sehingga jumlah sampel yang digunakan sebesar 97 sampel atau 60,62 persen dari total BPRS yang ada di Indonesia. Penelitian ini menggunakan dua periode penelitian, maka jumlah sampel yang digunakan berjumlah 194 firm years. Data yang digunakan dalam penelitian ini adalah data sekunder berupa laporan keuangan 
tahunan BPRS di Indonesia pada tahun 2011-2012 yang dipublikasikan di situs BI (dapat diakses pada alamat website www.bi.go.id).

Variabel dependen dalam penelitian ini adalah kinerja keuangan BPRS yang diukur dari lima rasio keuangan yaitu NPF, KPMM, FDR, ROA dan ROE. Kelima rasio keuangan tersebut sudah tersaji dalam laporan keuangan BPRS yang dapat diakses pada alamat www.bi.go.id. Sedangkan variabel independen yang digunakan dalam penelitian ini adalah empat komponen mekanisme corporate governance yaitu sebagai berikut ini. (1) Dewan komisaris independen, yang diukur berdasarkan persentase komisaris independen yang terdapat dalam perusahaan terhadap jumlah dewan komisaris. (2) Dewan direksi, yang diukur dengan menggunakan jumlah anggota direksi dalam suatu perusahaan. (3) Kepemilikan manajerial, yang diukur berdasarkan persentase saham yang dimiliki oleh manajemen terhadap jumlah saham yang diterbitkan. (4) Kepemilikan institusional, yang diukur dengan menggunakan persentase kepemilikan saham oleh institusi di dalam perusahaan.

Penelitian ini merupakan penelitian deskriptif kualitatif dan kuantitatif. Teknik analisis data yang digunakan dalam penelitian ini adalah analisis deskriptif dan Chi square didukung dengan analisis tabulasi silang (crosstab) dengan menggunakan program Microsoft Excel dan SPSS for Windows versi 16.

\section{HASIL DAN PEMBAHASAN}

\section{Statistik Deskriptif}

Statistik deskriptif yang digunakan untuk melihat sebaran data laporan keuangan tahunan BPRS periode 2011-2012 tersaji dalam Tabel 1. Berdasarkan data statistik deskriptif, secara umum BPRS di Indonesia selama tahun 2011 dan 2012 telah memenuhi Surat Keputusan Direksi Bursa Efek Jakarta No.Kep-399/BEJ/072001 butir C dan Peraturan BI Nomor 11/23/PBI/2009, yaitu jumlah komisaris independen telah lebih dari 30 persen dan jumlah direksi telah lebih dari dua orang. Sementara itu rata-rata kepemilikan manajerial dan kepemilikan institusional di BPRS selama tahun 2011 dan 2012 tidak terlalu besar. Terkait dengan kinerja keuangan BPRS, Tabel 1 tersebut juga menunjukkan secara rata-rata BPRS di Indonesia selama tahun 2011 dan 2011 memiliki kinerja keuangan yang diukur dari KPMM, ROA dan $R O E$ yang sangat baik karena telah melebihi ketentuan BI. Sedangkan rata-rata rasio NPF melebihi 7 persen dan rasio FDR masih kurang dari 93 persen, dimana hal ini masih belum sesuai ketentuan BI untuk dikategorikan sangat baik. 
Tabel 1

Statistik Deskriptif

\begin{tabular}{lrr}
\hline \multirow{2}{*}{ Variabel Penelitian } & \multicolumn{2}{c}{ Rata-rata } \\
\cline { 2 - 3 } & \multicolumn{1}{c}{$\mathbf{2 0 1 1}$} & \multicolumn{1}{c}{$\mathbf{2 0 1 2}$} \\
\hline Dewan Komisaris Independen (\%) & 48,7972 & 50,6872 \\
Dewan Direksi (orang) & 5,6907 & 5,6082 \\
Kepemilikan Manajerial (\%) & 1,2568 & 1,4922 \\
Kepemilikan Institusional (\%) & 18,3966 & 19,2742 \\
NPF (\%) & 8,1591 & 8,6280 \\
KPMM (\%) & 28,9897 & 30,7065 \\
FDR (\%) & 71,5752 & 87,2920 \\
ROA (\%) & 2,2979 & 5,9028 \\
ROE (\%) & 33,0633 & 55,9475 \\
\hline
\end{tabular}

Sumber: data diolah (2014)

\section{Hasil Pengujian Hipotesis}

Hasil pengujian hipotesis dengan menggunakan uji chi-square dapat dilihat pada Tabel 2.

Tabel 2

Hasil Pengujian Chi-Square

\begin{tabular}{|c|c|c|c|c|}
\hline & Variabel Penelitian & $\mathrm{x}^{2}$ Tabel & $\mathrm{x}^{2}$ Hitung & Kesimpulan \\
\hline \multirow[t]{5}{*}{ H1 } & Dewan Komisaris Independen-NPF & 26,296 & 22,079 & Hipotesis 1 tidak didukung \\
\hline & Dewan Komisaris Independen-KPMM & 26,296 & 11,578 & Hipotesis 1 tidak didukung \\
\hline & Dewan Komisaris Independen-FDR & 26,296 & 9,784 & Hipotesis 1 tidak didukung \\
\hline & Dewan Komisaris Independen- $R O A$ & 26,296 & 13,244 & Hipotesis 1 tidak didukung \\
\hline & Dewan Komisaris Independen- $R O E$ & 26,296 & 14,737 & Hipotesis 1 tidak didukung \\
\hline \multirow[t]{5}{*}{ H2 } & Dewan Direksi-NPF & 31,410 & 59,638 & Hipotesis 2 didukung \\
\hline & Dewan Direksi-KPMM & 31,410 & 10,843 & Hipotesis 2 tidak didukung \\
\hline & Dewan Direksi-FDR & 31,410 & 21,453 & Hipotesis 2 tidak didukung \\
\hline & Dewan Direksi-ROA & 31,410 & 9,720 & Hipotesis 2 tidak didukung \\
\hline & Dewan Direksi-ROE & 31,410 & 22,141 & Hipotesis 2 tidak didukung \\
\hline \multirow[t]{5}{*}{ H3 } & Kepemilikan Manajerial-NPF & 15,507 & 5,100 & Hipotesis 3 tidak didukung \\
\hline & Kepemilikan Manajerial-KPMM & 15,507 & 0,980 & Hipotesis 3 tidak didukung \\
\hline & Kepemilikan Manajerial-FDR & 15,507 & 9,936 & Hipotesis 3 tidak didukung \\
\hline & Kepemilikan Manajerial-ROA & 15,507 & 18,539 & Hipotesis 3 didukung \\
\hline & Kepemilikan Manajerial-ROE & 15,507 & 15,611 & Hipotesis 3 didukung \\
\hline \multirow[t]{5}{*}{ H4 } & Kepemilikan Institusional-NPF & 26,296 & 26,190 & Hipotesis 4 tidak didukung \\
\hline & Kepemilikan Institusional-KPMM & 26,296 & 18,610 & Hipotesis 4 tidak didukung \\
\hline & Kepemilikan Institusional-FDR & 26,296 & 17,215 & Hipotesis 4 tidak didukung \\
\hline & Kepemilikan Institusional-ROA & 26,296 & 14,259 & Hipotesis 4 tidak didukung \\
\hline & Kepemilikan Institusional-ROE & 26,296 & 29,267 & Hipotesis 4 didukung \\
\hline
\end{tabular}

Sumber: Data diolah, 2014 
Berdasarkan Tabel 2 ditemukan bahwa mekanisme corporate governance yang diukur dengan dewan direksi ditemukan berhubungan positif dengan kinerja keuangan BPRS dalam mengatasi kredit macet (NPF). Kepemilikan manajerial berhubungan positif dengan kemampuan profitabilitas BPRS, baik yang diukur dengan $R O A$ maupun $R O E$. Kepemilikan institusional berhubungan positif dengan kemampuan profitabilitas BPRS yang diukur dengan ROE. Namun sebagian besar dari indikator yang digunakan tidak terbukti berhubungan dengan variabel terikat, sehingga dapat disimpulkan bahwa mekanisme corporate governance yang diukur dengan dewan komisaris independen, dewan direksi, kepemilikan manajerial dan kepemilikan institusional tidak berhubungan dengan kinerja keuangan BPRS. Dengan demikian semua hipotesis yang diajukan tidak didukung oleh hasil penelitian.

Mekanisme corporate governance yang diukur dengan dewan komisaris independen ditemukan tidak berhubungan positif dengan seluruh kinerja keuangan BPRS yang diukur dari NPF, KPMM, FDR, ROA dan ROE. Dengan demikian H1 tidak didukung oleh hasil penelitian. Hal ini berarti bahwa persentase dewan komisaris independen tidak berhubungan dengan kemampuan BPRS dalam mengatasi tingkat kredit macet, kemampuan permodalan, likuiditas maupun kemampuan BPRS dalam pencapaian profitabilitas dari pemanfaatan aset dan ekuitasnya.

Tabel 3

Hasil Pengujian Tabulasi Silang

\begin{tabular}{|c|c|c|c|c|c|c|c|c|c|}
\hline \multirow{2}{*}{$\begin{array}{l}\text { Variabel } \\
\text { Penelitian }\end{array}$} & \multirow[b]{2}{*}{ Kriteria } & \multicolumn{2}{|c|}{$\begin{array}{c}\text { Dewan Komisaris } \\
\text { Independen }\end{array}$} & \multicolumn{2}{|c|}{$\begin{array}{c}\text { Jumlah Dewan } \\
\text { Direksi }\end{array}$} & \multicolumn{2}{|c|}{$\begin{array}{c}\text { Kepemilikan } \\
\text { Manajerial }\end{array}$} & \multicolumn{2}{|c|}{$\begin{array}{l}\text { Kepemilikan } \\
\text { Institusional }\end{array}$} \\
\hline & & $\begin{array}{c}< \\
33,3 \%\end{array}$ & $\begin{array}{c}\geq \\
33,3 \%\end{array}$ & $\begin{array}{c}< \\
\text { 5orang }\end{array}$ & $\begin{array}{c}\geq \\
5 \text { orang }\end{array}$ & $\begin{array}{c}\leq \\
10 \%\end{array}$ & $\begin{array}{c}> \\
10 \%\end{array}$ & $\begin{array}{c}\leq \\
20 \%\end{array}$ & $\begin{array}{c}>> \\
20 \%\end{array}$ \\
\hline \multirow[t]{2}{*}{$N P F$} & $\leq 7 \%$ & 30 & 74 & 10 & 104 & 107 & 7 & 86 & 28 \\
\hline & $>7 \%$ & 34 & 56 & 21 & 59 & 77 & 3 & 61 & 19 \\
\hline \multirow{2}{*}{ KPMM } & $\geq 11 \%$ & 53 & 110 & 28 & 135 & 154 & 9 & 123 & 40 \\
\hline & $<11 \%$ & 11 & 20 & 3 & 28 & 30 & 1 & 24 & 7 \\
\hline \multirow[t]{2}{*}{$F D R$} & $\geq 93 \%$ & 16 & 36 & 11 & 41 & 50 & 2 & 44 & 8 \\
\hline & $<93 \%$ & 48 & 93 & 20 & 122 & 134 & 8 & 103 & 39 \\
\hline \multirow[t]{2}{*}{$R O A$} & $>1,45 \%$ & 32 & 78 & 14 & 94 & 100 & 8 & 81 & 27 \\
\hline & $\leq 1,45 \%$ & 32 & 52 & 17 & 69 & 84 & 2 & 66 & 20 \\
\hline \multirow[t]{2}{*}{$R O E$} & $>23 \%$ & 19 & 49 & 7 & 61 & 61 & 7 & 51 & 17 \\
\hline & $\leq 23 \%$ & 45 & 81 & 24 & 102 & 123 & 3 & 96 & 30 \\
\hline
\end{tabular}

Sumber: data diolah (2014)

Dari Tabel 3 dapat diketahui bahwa ketika BPRS memiliki dewan komisaris lebih dari 33,3 persen ataupun kurang dari 33,3 persen, proporsi BPRS yang memiliki kinerja keuangan sangat baik dan kurang baik tidak jauh berbeda. Hal ini diduga sekalipun BPRS tidak memiliki dewan komisaris independen tetapi BPRS memiliki dewan pengawas syariah yang turut berperan dalam menjadikan semakin tingginya kinerja keuangan BPRS. Hasil penelitian ini tidak sejalan dengan 
penelitian Dhanis (2012), Diandono (2012) dan Widiawati (2011) yang membuktikan adanya pengaruh positif yang terdapat antara dewan komisaris independen dengan kinerja keuangan.

Sedangkan untuk mekanisme corporate governance yang diukur dengan jumlah dewan direksi, dari Tabel 2 ditemukan bahwa ada hubungan positif antara jumlah dewan direksi dengan kemampuan BPRS dalam mengatasi kredit macet $(N P F)$. Ini berarti bahwa dengan semakin banyak jumlah direksi di BPRS, maka akan pihak manajemen akan lebih berhati-hati dalam pelaksanaan kegiatan operasional BPRS, termasuk dalam pemberian kredit. Semakin banyak dewan direksi dalam perusahaan akan memberikan suatu bentuk pengawasan terhadap pemberian kredit yang semakin ketat, sehingga dapat menekan risiko ketidaktertagihan kredit yang diberikan. Namun hasil penelitian ini menemukan jumlah dewan direksi tidak berhubungan positif dengan kinerja lainnya (KPMM, FDR, ROA dan ROE). Dengan demikian H2 tidak didukung oleh hasil penelitian. Dari Tabel 3 disimpulkan bahwa ketika BPRS memiliki dewan direksi dengan jumlah lebih dari lima orang ataupun kurang dari lima orang, proporsi BPRS yang memiliki kinerja keuangan yang diukur dari KPMM, FDR, $R O A$ dan $R O E$, antara sangat baik dan kurang baik tidak jauh berbeda. Ini berarti bahwa banyaknya dewan komisaris dan dewan direksi pada BPRS tidak dapat menyebabkan peningkatan pada kemampuan BPRS dalam mengelola besaran modal sendiri, aspek likuiditas dan tingkat profitabilitas. Ada kemungkinan dewan direksi dalam jumlah yang besar dapat mengakibatkan kesulitan dalam hal komunikasi dan koordinasi antar sesama dewan, serta dapat menimbulkan kesulitan dalam hal pengambilan keputusan yang berguna bagi BPRS. Hasil penelitian ini tidak konsisten dengan penelitian Hutapea (2013) serta Rusmaryati (2012) yang menyatakan bahwa ukuran dewan direksi berpengaruh positif terhadap kinerja keuangan perusahaan.

Mekanisme corporate governance yang diukur dengan kepemilikan manajerial pada Tabel 2menemukan adanya hubungan positif dengan ROA dan ROE.Makin tinggi kepemilikan manajerial akan makin tinggi pula pencapaian profitabilitas dari segi pemanfaatan aset dan ekuitas BPRS. Semakin besar proporsi kepemilikan manajemen di BPRS, maka manajemen akan berupaya lebih giat dalam memenuhi kepentingan pemegang saham yang juga adalah dirinya sendiri, sehingga akan terdorong untuk meningkatkan kinerjanya. Adanya sistem insentif berbasis profitabilitas diduga juga menjadi pendorong manajemen untuk meningkatkan kinerja profitabilitas BPRS, sehingga makin tinggi profitabilitas maka makin tinggi insentif yang diterima oleh manajemen. Hasil penelitian ini sejalan dengan penelitian Melinda dan Sutejo (2008) yang membuktikan adanya pengaruh positif antara kepemilikan manajerial dengan kinerja keuangan. Namun kepemilikan manajerial ditemukan tidak berhubungan dengan kinerja keuangan BPRS lainnya, yaitu NPF, KPMM dan FDR, yang berarti besar kecilnya kepemilikan saham oleh manajemen tidak berhubungan dengan kemampuan BPRS dalam mengatasi kredit macet, 
permodalan maupun likuiditasnya. Dengan demikian H3 tidak didukung oleh hasil penelitian. Ada kemungkinan kepemilikan manajemen atas saham BPRS yang sangat kecil menyebabkan manajemen tidak memiliki pengendalian yang cukup atas penyaluran kredit, permodalan dan likuiditas BPRS. Tabel 3 juga mempertegas hal ini, dimana BPRS dengan kepemilikan manajerial lebih dari sepuluh persen atau kurang dari sepuluh persen, dimungkinkan untuk memiliki kinerja keuangan yang diukur dari NPF, KPMM dan FDR termasuk sangat baik ataupun kurang baik.

Selanjutnya Tabel 2 juga menjelaskan bahwa mekanisme corporate governance yang diukur dengan kepemilikan institusional ditemukan berhubungan positif dengan kemampuan BPRS dalam mencapai profitabilitas dengan memanfaatkan ekuitasnya. Temuan ini sejalan dengan pendapat Arifani (2012) bahwa adanya kepemilikan institusional dianggap sebagai kontroler bagi perusahaan untuk menciptakan kinerja yang baik dan semakin meningkat. Kinerja profitabilitas yang baik juga mencerminkan semakin tingginya efisiensi pengelolaan modal dan semakin efektifnya pengawasan oleh pemegang saham institusi. Namun hasil penelitian menunjukkan bahwa kepemilikan institusional tidak berhubungan dengan kemampuan BPRS dalam penanganan kredit macet, permodalan maupun likuiditasnya, sehingga H4 tidak didukung oleh hasil penelitian. Diduga pemisahan fungsi antara institusi pemegang saham dan manajemen pada BPRS telah dilakukan dengan baik, sehingga ketika BPRS memiliki kepemilikan institusional lebih dari 20 persen ataupun kurang, kemungkinan kinerja BPRS dalam penanganan kredit macet, permodalan maupun likuiditasnya, dapat sangat baik ataupun sebaliknya (lihat Tabel 3). Kapasitas pemegang saham institusi diduga hanyalah sebatas memberikan modal bagi dan memberikan pengawasan terhadap pencapaian profitabilitas dari pemanfaatan ekuitas BPRS. Pemegang saham institusi tidak turut campur dalam pengawasan terhadap kredit macet, kemampuan permodalan, aspek likuiditas dan pencapaian profitabilitas dari segi pemanfaatan aset BPRS.

\section{PENUTUP}

Dari hasil pengujian yang telah dilakukan telah ditemukan bahwa mekanisme corporate governance yang diwakili dewan direksi hanya berhubungan positif dengan kemampuan BPRS dalam mengatasi tingkat kredit macet (NPF), kepemilikan manajerial hanya berhubungan positif dengan pencapaian profitabilitas dari pemanfaatan aset dan ekuitas ( $R O A$ dan $R O E$ ) serta kepemilikan institusional hanya berhubungan positif dengan pencapaian profitabilitas dari pemanfaatan ekuitas $(R O E)$. Namun terkait dengan kinerja keuangan lainnya, khususnya dalam aspek permodalan (KPMM) dan likuiditas (FDR), mekanisme corporate governanceyang diukur dengan dewan komisaris independen, dewan direksi, kepemilikan manajerial dan kepemilikan institusional tidak berhubungan dengan kinerja keuangan BPRS. 
Dengan demikian semua hipotesis yang diajukan tidak didukung oleh hasil penelitian.

Hasil penelitian ini sejalan dengan penelitian yang dilakukan Sariningtyas (2011) yang menyatakan bahwa mekanisme corporate governance tidak berpengaruh terhadap kinerja keuangan perusahaan. Namun hasil penelitian ini tidak sejalan dengan penelitian Sekaredi (2011), Rusmaryati (2012) serta Andriyan dan Supatmi (2010) yang menyatakan bahwa mekanisme corporate governance berpengaruh terhadap kinerja keuangan perusahaan.Ketidakkonsistenan dengan hasil penelitian terdahulu dimungkinkan karena terdapat perbedaan proksi pada variabel corporate governance dan kinerja keuangan, serta perbedaan objek dan tahun penelitian.

Saran bagi BPRS, sebaiknya mempertimbangkan untuk memiliki jumlah dewan direksi lima sampai enam orang karena dalam penelitian ini ditemukan bahwa kinerja keuangan BPRS mencapai titik maksimal pada saat dewan direksi berjumlah lima sampai enam orang. Dalam penelitian ini ditemukan bahwa kepemilikan manajerial dan kepemilikan institusional pada BPRS di Indonesia masih sangat kecil, bahkan sebagian besar BPRS yang menjadi sampel penelitian tidak memiliki kepemilikan manajerial dan kepemilikan institusional. Sebaiknya dewan komisaris, direksi serta institusi meningkatkan kepemilikan sahamnya di BPRS, karena terbukti bahwa semakin tinggi kepemilikan manajerial dan kepemilikan institusional institusional, maka semakin tinggi pula pencapaian profitabilitas dari pemanfaatan aset dan ekuitas ( $R O A$ dan $R O E$ ).

Penelitian ini memiliki keterbatasan, yaitu periode pengamatan yang pendek dimana dalam penelitian ini hanya menggunakan dua periode penelitian saja, sesuai data yang tersedia di website Bank Indonesia. Oleh karena itu diharapkan pada penelitian mendatang perlu untuk memperluas periode penelitian untuk dapat menggambarkan hubungan mekanisme corporate governance terhadap kinerja keuangan BPRS.

\section{DAFTAR PUSTAKA}

Andriyan, O., dan Supatmi. 2010. Pengaruh mekanisme corporate governance terhadap kinerja keuangan bank perkreditan rakyat. Jurnal Akuntansi dan Keuangan Indonesia. Vol.7 No.2.

Ardianingsih, A., dan K. Ardiani. 2010. Analisis pengaruh struktur kepemilikan terhadap kinerja perusahaan. Jurnal Pena. Vol.19 No.2.

Bank Indonesia. 1999. Surat Keputusan Direktur Bank Indonesia Nomor 32/36/KEP/DIR/1999 Tanggal 12 Mei 1999 tentang Bank Perkreditan Rakyat Berdasarkan Prinsip Syariah.

- 2001. Surat Edaran Bank Indonesia Nomor 3/30/DPNP tanggal 14 Desember 2001 tentang Pedoman Perhitungan Rasio Keuangan. 
2001. Peraturan Bank Indonesia Nomor 3/15/PBI/2001 tentang Penetapan Status Bank Perkreditan Rakyat dalam Pengawasan Khusus dan Pembekuan Kegiatan Usaha.

. 2006. Peraturan Bank Indonesia Nomor 8/4/PBI/2006 tentang Pelaksanaan Good Corporate Governance Bagi Bank Umum.

2006. Peraturan Bank Indonesia Nomor 8/14/PBI/2006 tentang Perubahan Peraturan Bank Indonesia Nomor 8/4/PBI/2006 tentang Pelaksanaan Good Corporate Governance Bagi Bank Umum.

. 2007. Surat Edaran Bank Indonesia Nomor 9/29/DPbS tanggal 7 Desember 2007 tentang Sistem Penilaian Tingkat Kesehatan Bank Perkreditan Rakyat Berdasarkan Prinsip Syariah.

. 2009. Peraturan Bank Indonesia Nomor 11/23/PBI/2009 Tanggal 1 Juli 2009 tentang Bank Pembiayaan Rakyat Syariah.

Daniri, M. A. 2005. Good Corporate Governance Konsep Dan Penerapannya Dalam Konteks Indonesia. Jakarta: Ray Indonesia.

Dhanis, R. P. S. U. 2012. Pengaruh mekanisme good corporate governance terhadap kinerja keuangan perbankan yang terdaftar di Bursa Efek Indonesia tahun 2008-2010. Skripsi. Fakultas Ekonomi Universitas Negeri Yogyakarta. Available at http://eprints.uny.ac.id.

Diandono, H. 2012. Pengaruh mekanisme good corporate governance (GCG) terhadap kinerja keuangan pada perusahaan yang masuk kelompok Jakarta Islamic Index (JII) periode 2006-2011. Skripsi. Universitas Islam Negeri Sunan Kalijaga Yogyakarta. Available at http://digilib.uin-suka.ac.id.

Direksi Bursa Efek Jakarta. 2001. Surat Keputusan Direksi Bursa Efek Jakarta No.Kep-399/BEJ/07-2001 Tanggal 20 Juli 2001 tentang Peraturan Pencatatan Efek Nomor I-A Huruf C.

Hutapea, A. J. 2013. Analisis pengaruh corporate governance terhadap kinerja keuangan sektor perbankan (studi pada perusahaan perbankan yang terdaftar di BEI tahun 2007-2011. Skripsi. Universitas Diponegoro Semarang. Available at http://eprints.undip.ac.id.

Komite Nasional Kebijakan Governance. 2006. Pedoman Umum Good Corpotate Governance Indonesia. Jakarta: Menteri Koordinator Bidang Perekonomian Republik Indonesia.

Melinda, F. I., dan B. S. Sutejo. 2008. Interdependensi kepemilikan manajerial dan kepemilikan institusional terhadap kinerja keuangan. Manajemen \& Bisnis. Vol.7 No.2. 
Noorizkie, G. 2013. Pengaruh mekanisme corporate governance terhadap kinerja keuangan perusahaan (studi empiris pada perusahaan manufaktur yang terdaftar di Bursa Efek Indonesia). Skripsi. Universitas Diponegoro Semarang. Available at http://eprints.undip.ac.id.

Nuryaman. 2009. Pengaruh konsentrasi kepemilikan, ukuran perusahaan dan mekansime corporate governance terhadap pengungkapan sukarela. Jurnal Akuntansi dan Keuangan Indonesia. Vol.6 No.1.

Purwaningtyas, F. P. 2011. Analisis pengaruh mekanisme good corporate governance terhadap nilai (studi empiris pada perusahaan manufaktur yang terdaftar di BEI tahun 2007-2009). Skripsi. Universitas Diponegoro Semarang. Available at http://eprints.undip.ac.id.

Rahmayanti, E. 2012. Analisis pengaruh mekanisme corporate governance terhadap earnings management dan kinerja perusahaan (studi empiris perusahaan manufaktur yang terdaftar di Bursa Efek Indonesia periode 2006-2011). Jurnal Ekonomi dan Bisnis. Vol.3 No.1.

Republik Indonesia. 1998. Undang-Undang Pokok Perbankan Nomor 10 Tahun 1998. Lembaran Negara RI, No.10. Jakarta: Sekretariat Negara. . 2007. Undang-Undang Perseroan Terbatas Nomor 40 Tahun 2007. Jakarta: Sekretariat Negara.

. 2008. Undang-Undang Tentang Perbankan Syariah Nomor. 21 Tahun 2008 Pasal 1 Angka 9. Jakarta: Sekretariat Negara.

Rusmaryati, D. F. 2012. Pengaruh penerapan mekanisme good corporate governance terhadap kinerja keuangan perbankan konvensional yang terdaftar di Bursa Efek Indonesia tahun 2009-2011. Skripsi. Fakultas Ekonomi Universitas Negeri Yogyakarta. Available at http://eprints.uny.ac.id.

Sariningtyas, R. 2011. Pengaruh good corporate governance terhadap kinerja keuangan perusahaan yang termasuk dalam corporate governance perception index (CGPI) tahun 2005-2009. Skripsi. Universitas Negeri Malang. Available at http://karya-ilmiah.um.ac.id.

Sekaredi, S. 2011. Pengaruh corporate governance terhadap kinerja keuangan perusahaan (studi pada perusahaan yang terdaftar di LQ45 tahun 2005-2009). Skripsi. Universitas Diponegoro Semarang. Available at http://eprints.undip.ac.id.

Syakhroza, A. 2002. Mekanisme pengendalian internal dalam melakukan assessment pelaksanaan good corporate governance. Manajemen Usahawan. No.8 Tahun XXXI.

Wahyuni, A. S., dan Nuryaman. 2010. Pengaruh kepemilikan institusional, kepemilikan manajerial dan proporsi dewan komisaris independen terhadap 
kualitas laba pada perusahaan manufaktur yang terdaftar di Bursa Efek Indonesia. Skripsi. Universitas Widyatama Bandung. Available at http://repository.widyatama.ac.id.

Widiawati, H. S. 2011. Pengaruh corporate governance terhadap kinerja keuangan (studi empiris pada perbankan di Bursa Efek Indonesia). Tesis. Universitas Sebelas Maret Surakarta. Available at http://library.uns.ac.id.

Widyati, M. F. 2013. Pengaruh dewan direksi, komisaris independen, komite audit dan kepemilikan institusional terhadap kinerja keuangan. Jurnal Ilmu Manajemen. Vol.1 No.1. 